\title{
REVISITING JAPANESE FOOD CONSUMPTION PATTERNS
}

\author{
Abdullah Alias, Hajime Kobayashi, Ichizen Matsumura, Hassan Maizom, \\ Zakaria Mustafa, Md Nasrudin Md Akhir, Rohayati Paidi, Asmadi Hassan and \\ Mohd Ikbal Mohd Huda
}

\section{Introduction}

Japanese food consumption pattern has been undergoing dramatic changes over the last 40 years. There have been increasing consumption of meats, bread, other cereals and beverages, and decreasing consumption of rice, noodles, fish and shellfish, dairy products, oil and fats, cakes and candies, juices, alcohol, fresh fruits, as well as fresh vegetables in Japan. Many economists have attributed these changes to such factors as higher household income, aging population, and more westernization in lifestyle. However, Japanese household income has been decreasing after 1993 that makes most of the food consumption declining. ${ }^{1}$ Undoubtedly, many factors have influenced Japanese food consumption pattern. Understanding of these factors is very important for market assessment of agricultural products in Japan.

Since Japan is one of the largest agricultural importing countries, its changing food consumption pattern would directly affect the world agricultural trade. The question such as whether rice is an inferior good is important as a main key in evaluating the significance of Japanese domestic agricultural policy in the WTO negotiation that also affected other agriculture products; with our interest more on fresh fruits. This study attempts to provide econometric evidence for answering such questions, using a crosssectional data analysis. The objectives of this study are to analyze the food consumption patterns and to conduct econometric analyses of food demand structure in Japan by special analyses on rice and meat as key determinant factors. The analysis on food consumption pattern is very important in order to understand the consumption of different kind of foods consumed by Japanese household.

\section{Materials and Methods}

Specifically, we use the household data from several issues of the Family Income and Expenditure Survey (FIES) from 1976-2010 obtained from the Statistics Bureau, Management and Coordination Agency under the collaboration with the National Research Institute of Agricultural Economics (NRIAE) in Tokyo. This study is relatively unique because it is based on household level data while most of the literature on food demand analysis in Japan used aggregate data at the national level or by aggregate demographic groups. The use of household data enables us to analyze the impacts

${ }^{1}$ FAO Food and Agriculture Organization, 'Analysis of Food Consumption Behaviour by Japanese Household', 2002, Retrieved July 1, 2010, http:/ / www.fao.org/docrep/007/ ae025e/ae025e00.htm. 
of important demographic variables affecting food consumption patterns in Japan. The large number of households in the FIES provides higher degrees of freedom in econometric estimation than many previous studies using time-series data. This is particularly important for estimating income elasticities of such important foods especially for two periods of our studies (1973-1991 and 1991-2008). The household data should be able to shed more light on such issues, as whether or not the position of food demand has changed the position over time either from price elastic to price inelastic or from luxury to either normal or inferior good (or vice versa).

Two specific periods for food demand studies are undertaken in this study: 19731991 and 1991-2008. The elasticity of demand for fourteen aggregate food groups was calculated, and the comparison of the elasticities values between 2 periods as well as the cross price elasticity for the latter period were carried out for further analysis. The fourteen categories of food undertaken in this study are rice, bread, noodles, other cereals, dairy products, fish and shellfish, meat, fruits, vegetables, cakes and candies, oil and fats, alcohol, coffee and tea and juices (fruit and vegetable) as shown in Table 1. For the remainder of this report, descriptive statistics describing the food consumption patterns in Japan, the survey, the models used, econometric estimation results, estimated demand elasticities and their implications will be presented.

The application of the theory of the household requires a specific model. However, for this paper, the differentiated double-logarithmic function was utilized. The function was employed in a least square multiple regression analysis to best fits the available data. The estimation was carried out using differentiated double logarithmic linear function which is easier to work compared to other linear model because elasticity values are simple constants and equal to the exponential value.

Let the demand system derived from a consumer's utility maximization be ;

$$
\Delta \log Q=\alpha+\beta \Delta \log (P / C P I)+\gamma \Delta \log (Y / C P I)+D
$$

where;

Q: $\quad$ Quantity demanded

$P$ : $\quad$ Nominal price

$Y$ : $\quad$ Nominal living expenditure $\quad \gamma:$ Expenditure elasticity

$C P I$ : Consumer price index $\quad D$ : Dummy variable

*Note : Estimated by the generalized least squares method

From the equation, we can derive the elasticity values for the commodities. We used SHAZAM software for our regression analysis.

\section{RESULTS AND DISCUSSION}

One of main objectives of this study is to analyze food consumption patterns and to conduct simple econometric analysis of food demand structure in Japan. We use the cross-sectional household data from the Family Income and Expenditure Survey (FIES) 1974-2009, conducted by the Statistics Bureau, Management and Coordination Agency in Japan. The total number of observations used for estimation is 95,223. Food items are rice, noodles, fish and shellfish, dairy products, oil and fats, cakes and candies, juices, alcohol, fresh fruits and fresh vegetables This research is unique in the sense that income elasticity of rice and other related foods are estimated with immense degrees 


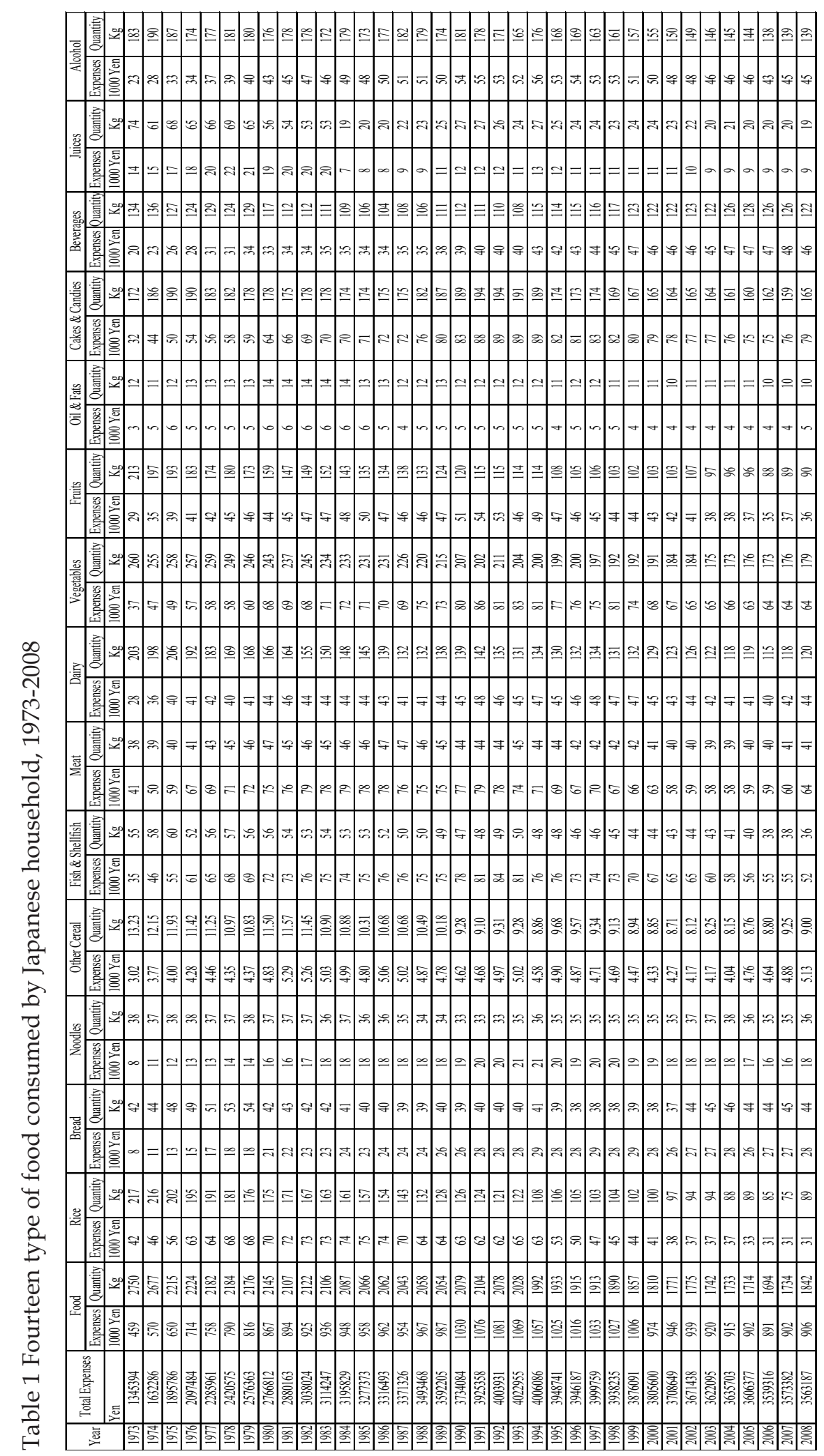


Abdullah Alias, Hajime Kobayashi, Ichizen Matsumura, Hassan Maizom, Zakaria Mustafa, Md Nasrudin Md Akhir, Rohayati Paidi, Asmadi Hassan and Mohd Ikbal Mohd Huda

Table 2 Fourteen food products elasticity, 1973-1991 and 1991-2008

\begin{tabular}{|c|c|c|c|c|c|}
\hline \multirow[b]{2}{*}{ \# } & \multirow[b]{2}{*}{ Items } & \multicolumn{2}{|c|}{ 1973-1991 } & \multicolumn{2}{|c|}{ 1991-2008 } \\
\hline & & $\begin{array}{c}\text { Price } \\
\text { Elasticity }\end{array}$ & $\begin{array}{c}\text { Expenditure } \\
\text { Elasticity } \\
\end{array}$ & $\begin{array}{c}\text { Price } \\
\text { Elasticity }\end{array}$ & $\begin{array}{c}\text { Expenditure } \\
\text { Elasticity }\end{array}$ \\
\hline \multirow[t]{2}{*}{1} & Rice & -1.242 & -0.293 & -1.387 & -0.726 \\
\hline & & $(0.003)^{* * *}$ & $(0.576) * * *$ & $(0.000) * * *$ & $(0.079)^{* *}$ \\
\hline \multirow[t]{2}{*}{2} & Bread & -0.854 & 0.240 & -1.388 & 0.668 \\
\hline & & $(0.000)^{* * *}$ & $(0.701)^{* * *}$ & $(0.000)^{* * *}$ & $(0.230)^{*}$ \\
\hline \multirow[t]{2}{*}{3} & Noodles & -0.658 & 0.507 & -0.976 & -0.609 \\
\hline & & $(0.000)^{* * *}$ & $(0.666)^{* * *}$ & $(0.006)^{* * *}$ & $(0.536)^{*}$ \\
\hline \multirow[t]{2}{*}{4} & Other Cereals & -1.205 & -0.959 & -0.941 & -0.685 \\
\hline & & $(0.000)^{* * *}$ & $(0.469)^{* * *}$ & $(0.167)^{*}$ & $(0.691)^{*}$ \\
\hline \multirow[t]{2}{*}{5} & Dairy & -0.792 & 1.388 & -1.313 & 0.549 \\
\hline & & $(0.049)^{* *}$ & $(0.804)^{* * *}$ & $(0.248)^{*}$ & $(0.144)^{*}$ \\
\hline \multirow[t]{2}{*}{6} & Fish \& Shellfish & -0.805 & 1.180 & -1.483 & 0.687 \\
\hline & & $(0.000)^{* * *}$ & $(0.022)^{* *}$ & $(0.080)^{* *}$ & $(0.408)^{*}$ \\
\hline \multirow[t]{2}{*}{7} & Meat & -0.470 & 1.774 & -0.743 & 1.062 \\
\hline & & $(0.003)^{* * *}$ & $(0.668)^{*}$ & $(0.000)^{* * *}$ & $(0.169)^{*}$ \\
\hline \multirow[t]{2}{*}{8} & Fruits & -0.515 & 1.097 & -1.343 & 0.799 \\
\hline & & $(0.001)^{* * *}$ & $(0.067)^{* *}$ & $(0.000)^{* * *}$ & $(0.084)^{* *}$ \\
\hline \multirow[t]{2}{*}{9} & Vegetables & -0.870 & 0.553 & -1.264 & 0.820 \\
\hline & & $(0.000)^{* * *}$ & $(0.109)^{*}$ & $(0.000)^{* * *}$ & $(0.104)^{*}$ \\
\hline \multirow[t]{2}{*}{10} & Cakes \& Candies & -0.247 & 1.339 & -2.164 & 1.240 \\
\hline & & $(0.932)^{*}$ & $(0.215)^{*}$ & $(0.750)^{*}$ & $(0.067)^{* *}$ \\
\hline \multirow[t]{2}{*}{11} & Oil \& Fats & -0.925 & 0.806 & -1.093 & 0.228 \\
\hline & & $(0.000)^{* * *}$ & $(0.223)^{*}$ & $(0.002)^{* * *}$ & $(0.011)^{* *}$ \\
\hline \multirow[t]{2}{*}{12} & Alcohol & -0.268 & 1.256 & -1.736 & 0.833 \\
\hline & & $(0.402)^{*}$ & $(0.608)^{*}$ & $(0.037)^{* *}$ & $(0.251)^{*}$ \\
\hline \multirow[t]{2}{*}{13} & Coffee and Tea & -0.668 & 1.463 & -1.759 & 0.794 \\
\hline & & $(0.052)^{* *}$ & $(0.188)^{*}$ & $(0.089)^{* *}$ & $(0.226)^{*}$ \\
\hline \multirow[t]{2}{*}{14} & Juices & -0.629 & 1.418 & -1.608 & 0.707 \\
\hline & & $(0.800)^{*}$ & $(0.005)^{* * *}$ & $(0.025)^{* *}$ & $(0.008)^{* * *}$ \\
\hline
\end{tabular}

Source: Various issues of FIES, 1974-2009

of consumption patterns. In order to incorporate household-level micro data, we apply double logarithmic equation models and generate the value using SHAZAM software as mentioned earlier. All coefficients have correct signs and are statistically significant less than $5 \%$.

In general, the household demand analyses for 14 food products have shown different trends as shown in Table 2. Table 2 refers to almost all of the price elasticities for all types of food less than -1 (or 1) except for rice and other cereals for the period of 1973-1991. It means; generally, Japanese food demand is price inelastic that explains the food consumption in Japan not depend so much on price. However, for the latter period of 1991-2008, only noodles, other cereals and meat have the price elasticity values less than 0. Increase in price will lead the demand for most of the food decrease. Price has becomes more important determinant as the economy becomes more uncertain especially after the bubble economy.

On the other hand, expenditure elasticity values for most of the food for the first period are positive and more than one except for rice, bread, noodles, cereals and vegetables with only rice and other cereals have a negative sign. With most of the food classified as a luxury, rice and other cereals considered as inferior good. Increase in income will not lead to the increases in demand for rice and other cereals. Second 
Table 3 Cross price elasticities for 14 foods, 1991-2008

\begin{tabular}{|l|l|r|r|r|r|r|r|r|r|r|r|r|r|r|r|}
\hline$\#$ & \multicolumn{1}{|c|}{ Items } & Rice & Bread & Noodles & $\begin{array}{c}\text { Other } \\
\text { Cereals }\end{array}$ & Dairy & $\begin{array}{r}\text { Fish \& } \\
\text { Shellfish }\end{array}$ & Meat & Fruit & Vegetable & $\begin{array}{c}\text { Cakes \& } \\
\text { Candies }\end{array}$ & $\begin{array}{r}\text { Oil \& } \\
\text { Fats }\end{array}$ & Alcohol & $\begin{array}{c}\text { Coffee \& } \\
\text { Tea }\end{array}$ & Juice \\
\hline 1 & Rice & -1.387 & -0.411 & -0.343 & 0.039 & -0.888 & 0.801 & 0.225 & 0.760 & 0.391 & 0.508 & 0.505 & 0.738 & -0.335 & 0.985 \\
2 & Bread & 3.263 & -1.388 & -1.153 & 0.132 & -2.986 & 2.696 & 0.758 & 2.555 & 1.316 & 1.709 & 1.697 & 2.484 & -1.127 & 3.313 \\
3 & Noodles & 1.543 & -0.654 & -0.976 & 0.063 & -1.413 & 1.275 & 0.359 & 1.209 & 0.623 & 0.809 & 0.803 & 1.175 & -0.533 & 1.567 \\
4 & Other Cereals & -2.619 & 1.109 & 0.926 & -0.941 & 2.397 & -2.164 & -0.608 & -2.051 & -1.057 & -1.372 & -1.362 & -1.994 & 0.905 & -2.659 \\
5 & Dairy & -5.185 & 2.197 & -0.634 & -0.210 & -1.313 & -4.285 & -1.204 & -4.061 & -2.092 & -2.717 & -2.697 & -3.948 & 1.791 & -5.265 \\
6 & Fish \& Shellfish & 1.795 & -0.760 & -0.763 & 0.073 & -1.643 & -1.483 & 0.417 & 1.406 & 0.724 & 0.940 & 0.934 & 1.367 & -0.620 & 1.822 \\
7 & Meat & 2.159 & -0.915 & -0.763 & 0.087 & -1.977 & 1.784 & -0.743 & 1.691 & 0.871 & 1.131 & 1.123 & 1.644 & -0.746 & 2.192 \\
8 & Fruits & 2.135 & -0.905 & -0.755 & 0.086 & -1.954 & 1.764 & 0.496 & -1.343 & 0.861 & 1.119 & 1.111 & 1.626 & -0.738 & 2.168 \\
9 & Vegetables & 1.727 & -0.732 & -0.611 & 0.070 & -1.581 & 1.427 & 0.401 & 1.353 & -1.264 & 0.905 & 0.899 & 1.315 & -0.597 & 1.754 \\
10 & Cakes \& Candies & -5.185 & 2.197 & 1.833 & -0.210 & 4.746 & -4.285 & -1.204 & -4.061 & -2.092 & -2.164 & -2.697 & -3.948 & 1.791 & -5.265 \\
11 & Oil \& Fats & -2.722 & 1.153 & 0.962 & -0.110 & 2.491 & -2.249 & -0.632 & -2.132 & -1.098 & -1.426 & -1.093 & -2.073 & 0.940 & -2.764 \\
12 & Alcohol & -5.194 & 2.200 & 1.836 & -0.210 & 4.754 & -4.292 & -1.206 & -4.068 & -2.095 & -2.721 & -2.702 & -1.736 & 1.794 & -5.273 \\
13 & Coffee \& Tea & -5.185 & 2.196 & 1.833 & -0.210 & 4.746 & -4.284 & -1.204 & -4.061 & -2.092 & -2.716 & -2.697 & -3.948 & -1.759 & -5.264 \\
14 & Juices & 0.328 & 2.197 & 1.833 & -0.210 & 4.746 & -4.285 & -1.204 & -4.061 & -2.092 & -2.717 & -2.697 & -3.948 & 1.791 & -1.608 \\
\hline
\end{tabular}

Source: Self-projection

period (1991-2006) has shown that most of the foods are normal good (increase income will increase in demand). Only meat, and cakes and candies considered as luxury food while rice, noodles and other cereals are classified as inferior goods as agreed by many previous researches.

\section{a) A cross-price elasticities analysis}

The cross-price elasticity from whole-sample is shown in Table 3. First of all the results indicate that 7 foods (other cereal, dairy, cakes and candies, oil and fats, alcohol, coffee and tea and juices) are complement to majority of other food while other 7 (rice, bread, noodles, fish and shellfish, meat, fruit, and vegetables) have majority substitute to other food. Other cereals, dairy product, cakes and candies, oil and fats, alcohol, and coffee and tea are compliment to rice. Meat is substitutes to rice, bread, noodles, fish and shellfish, fruits, and vegetables. While, fruit is a complement to most of the food except for rice, bread, noodles, fish and shellfish, meat, and vegetables.

Referring to Table 3, price elasticity values for most of the foods for 1991-2008 are high with the value more than 1 except for noodles, other cereals and meat. Rice and bread becomes very important as a main food in Japanese society. Since rice and bread are substitutes to each other, the increases of price in rice will shift the demand to bread. Fresh fish and shellfish have higher own-price elasticity than fresh meat. There are some possible reasons behind this finding. First of all, the importance of fish in the Japanese diet reflects this result. The fish eating culture in Japan has induced a wide range of variations in fish prices and its consumption levels. Second, fish has many varieties for its kind and for its use. These varieties offer many substitution opportunities, which tend to result in higher own-price elasticity. The high elasticities for dairy product are expected despite not much variations of price for those products. Dairy products are getting popular with the massive advertising from some famous brand such as Meiji、Koiwai, Glico and Snow as well as other local brand. 
Combining this finding with the results from Table 3, there is a possibility that rice is not a staple food any longer. It is interesting to note that fresh fish has higher expenditure elasticity than fresh meat. Again, this result shows the importance of fish in the Japanese diet. Recently, meat consumption has been increasing (after 2005), while the high price and expenditure elasticity shows that consumers are sensitive for fish price and their income when they determine their consumption patterns. Another possibility is that processed meats like ham, sausage, and bacon, are not included in the category of fresh meat. The inclusion of processed meats might change the result. The price elasticity is relatively high for fresh fruits. This might be a reflection of the fact that the fruits are relatively costly amongst the goods in question. In the marketplace, there always exist more expensive fruits than the one a consumer purchased. Additionally, it might be true that some fruits are purchased as gifts.

\section{b. Rice Demand Analysis}

i) Introduction

Japan reached high per capita income much earlier than other Asian nations. As per capita income grew, the food consumption pattern changed. Many studies have reported that the Japanese diet has become more westernized; calorie intake is less from rice and more from animal meat and the fat content of food has increased. Because of geographical reasons and preferences, calorie intake from fish has a larger share than from meat in a Japanese diet. In this section, we have an overview of time trend of rice consumption patterns.

Figure 1 Annual Japanese household rice consumption, 1973-2008

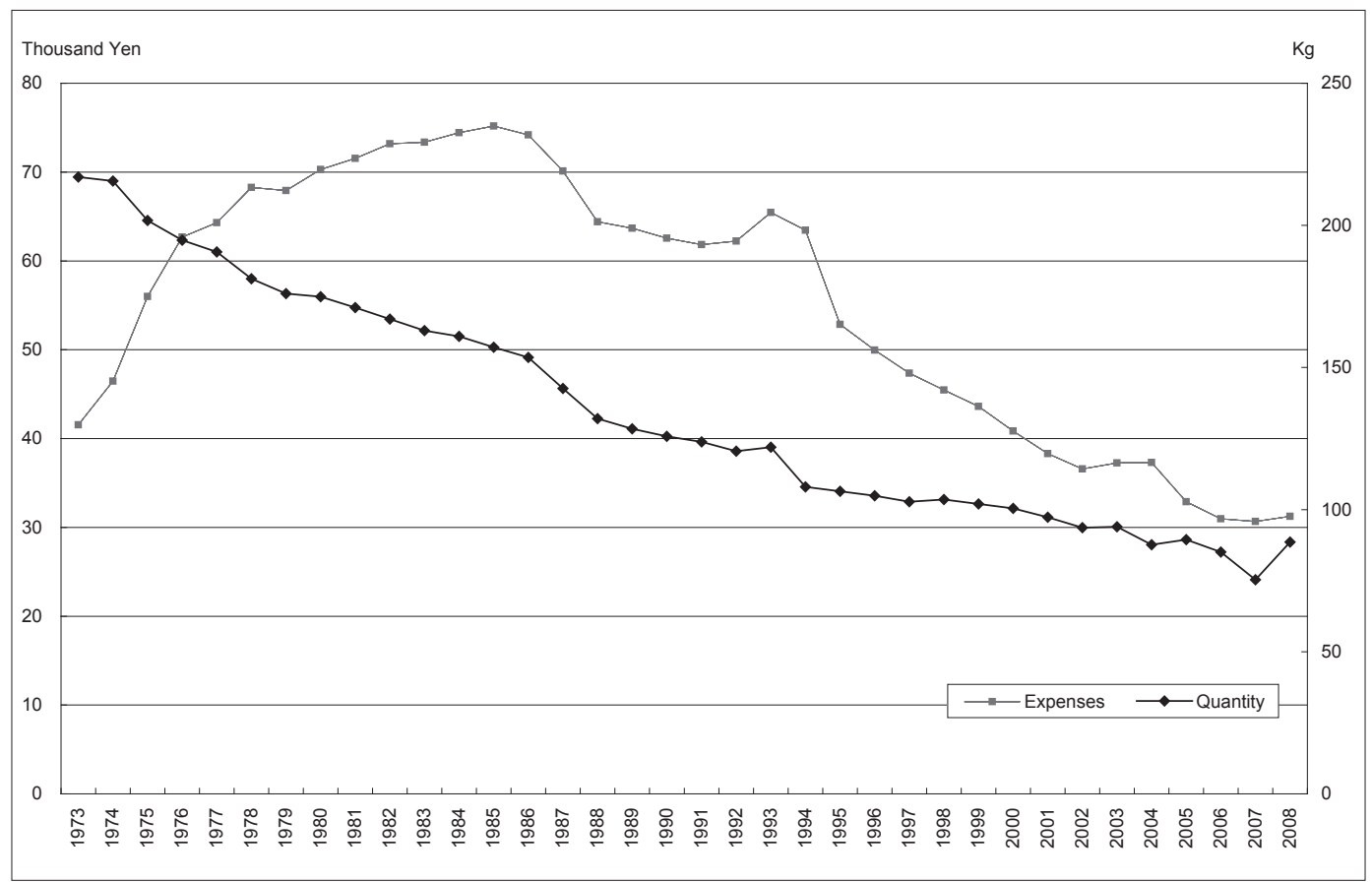

Source: FIES, 1974-2009 
Figures 1 show descriptive consumption patterns in Japan from 1973-2008. All data are taken from the various issues of Annual Reports on the Family Income and Expenditure Survey 1974-2009. This is consumption side data; data are summed up on how much food items are consumed by the Japanese household. Figure 1 plots the annual household rice consumption and total expenses for rice in Japan. It is a well known fact that aggregate rice consumption in Japan has been declining over the years, which is common amongst high-income countries. The peak of the per capita consumption of rice occurred in 1962 and has been decreasing ever since. ${ }^{2}$

Sawada ${ }^{3}$ studied Japanese food demand system using the Rotterdam model. ${ }^{4}$ Monthly survey data covered from 1956 to 1975. The food items included cereal, fish, meat, egg, vegetable, fruits, food away from home, other food, and non-food. Expenditure elasticity for rice (-0.395) was negative, and rice was only the item, which showed a negative expenditure elasticity. Own-price elasticities for rice, fish, meat, and food away from home were $-0.17,-0.545,-0.799$, and -0.353 , respectively. Utilizing monthly time-series survey data from 1964 to 1979, Sawada estimated price and expenditure elasticities with AIDS model in Japan. Results indicated that ownprice elasticities for staple food, fish, meat, and food away from home were -0.903 , $-1.125,-0.981$, and -1.522 , respectively. ${ }^{5}$ Own-price elasticity was particularly high for staple food, and it was similar to meat. In another study, Sawada ${ }^{6}$ used a two-level Food Demand System to estimate own-price and cross-price elasticities for seventeen products in Japan. Data were taken from Family Income and Expenditure Survey, and they were monthly time-series from 1963 to 1981 . Rice own-price elasticity was -0.26 , and its expenditure elasticity was -0.73 . It is noteworthy that only rice expenditure elasticity is negative amongst seventeen products. Results indicated that the magnitude of price elasticity was similar to expenditure elasticity in absolute term, i.e. if a good is price elastic, then it tends to be expenditure elastic as well. It is interesting to see that expenditure elasticity for beef (1.93) was the highest amongst seventeen goods, and expenditure elasticity for food away from home was the second highest (1.82). Sawada later estimated income elasticities of cereal and related goods using survey data from 1976 to 1984 by means of generalized Houthakker's method. ${ }^{7}$ The author concluded that demand was largely influenced by income, the number of household members, and the household head's age $(\mathrm{FAO}, 2002){ }^{8}$

\footnotetext{
2 Alias Abdullah, Hajime Kobayashi, Ichizen Matsumura, Shoichi Ito, 'World Rice Demand Towards 2050: Impact of Decreasing Demand of per Rice Consumption for China and India'. In Japan and East Regionalism, Md. Nasrudin Md Akhir and Asmadi Hassan (eds), Department of East Asian Studies, University of Malaya, 2008.

3 H. Sawada, 'Estimation of food demand system: Rotterdam demand system approach', Hokusei Ronsyu, 18, 1980, pp. 147-161.

4 FAO Food and Agriculture Organization, 'Analysis of Food Consumption Behaviour by Japanese Household', 2002.

5 M. Sawada, 'Changes in total expenditure distribution and aggregate food demand of household sector', Journal of Rural Economics, Vol. 54, No. 4, 1983, pp. 185-195.

6 H. Sawada (1984) Sawada, M.,'A hierarchical model of demand for food in Japan', Journal of Rural Economics, Vol. 56, No.3, 1984, pp.163-173

7 M. Sawada,'The effects of prices, income and household characteristics on food demand: a demand system approach', Journal of Rural Economics, Vol. 57, No.4, 1986, pp. 229-239.

8 FAO Food and Agriculture Organization, 'Analysis of Food Consumption Behaviour by Japanese Household', 2002.
} 
Price elasticity for food was small compared to income elasticity, and this tendency was particularly strong with respect to the number of household members. Bouis ${ }^{9}$ objected to the study of IPG; the author claimed that time-series estimates of grain consumption have a downward bias due to the urban-rural migration pattern and decreasing importance of rice production. ${ }^{10}$ From a estimated calorie-income elasticity, cross-sectional data estimates of income elasticity are upwardly biased due to leakage from actual consumption, such as meals for guests and animal feeding in developing countries. As Chern ${ }^{11}$ and Huang and Bouis ${ }^{12}$ pointed out, plotting aggregate consumption against per capita income simply showed the correlation between two variables. It did not necessarily reveal the true consumption behavior.

\section{ii) Is Rice an Inferior Good in Japan?}

Rice is a staple food in Japan, and its great importance in the Japanese diet is well known. ${ }^{13}$ According to the United States Department of Agriculture (USDA) in 2008, 8.9 million metric tons of rice was produced domestically, and 8.3 million metric tons were consumed. Rice is used by a variety of sectors, but mostly by the household. In $2008,93.21 \%$ of rough rice was purchased by the milling sector, and $74.38 \%$ of milled rice was consumed directly by households. ${ }^{14}$ Japan is the highest per capita GDP in the world. If rice were an inferior good, by definition, rice consumption would keep falling with per capita GDP growth. If that were the case, and if Japan could be considered as the leading case for other Asian countries, we could project lower world rice demand in the future as Asian nations' income increases. It has been considered as the stylized fact among researchers that income elasticities for rice and other food staples decline as per capita income increases. Researchers believe that rice in developed countries such as Japan became an inferior good a few decades ago.

There is conflicting evidence on whether rice is an inferior good. One of the most influential studies on rice consumption in Asia is an empirical study conducted by Ito, Peterson, and Grant (IPG). ${ }^{15}$ Utilizing aggregate national level data, Ito and colleagues concluded that rice was an inferior good in high-income Asian countries, and they estimated income elasticity of rice in Japan to be -0.091 in 1964 and -0.708 in 1984 . Kako, Gemma, and Ito ${ }^{16}$ projected Japanese rice demand applying a log linear function

9 H, E., Bouis, 'Rice in Asia: Is it becoming a commercial good? Commentary, American Journal of Agricultural Economics, Vol.73, pp. 522-527, 1991.

10 FAO Food and Agriculture Organization, 'Analysis of Food Consumption Behaviour by Japanese Household', 2002.

11 W. S., Chern, 'Assessment of demand side factors affecting global food security'. In W.S. Chern, C.A. Carter and S.-Y. Shei, eds. Food security in Asia: economics and policies, Northampton, Massachusetts, USA, Edward Elgar, 2000.

12 J. Huang and B. Howard B, Structural Changes in the Demand for Food in Asia, Washington, D.C.: International Food Policy Research Institute, 1986.

13 FAO Food and Agriculture Organization, 'Analysis of Food Consumption Behaviour by Japanese Household', 2002.

14 MAFF, Statistics and Information Department, Food Balance Sheet, Ministry of Agriculture, Forestry and Fisheries 2001, Management and Coordination Agency, Government of Japan, 1999.

15 S. Ito, P. Wesley and G. Warren, 'Rice in Asia: Is It Becoming an Inferior Good?' American Journal of Agricultural Economics, Vol.71, 1989, pp. 32-42.

16 T. kako, M. Gemma, \& S. Ito, 'Implication of the minimum access rice import on supply and demand balance of rice in Japan', Agricultural Economics, Vol. 16, 1997. 
estimated by OLS using the time series data of the period 1970-1991. Authors supported IPG results; they found evidence that rice was an inferior good and meat products were substitutes for rice. Estimated own price elasticity was -0.130 , and expenditure elasticity was -0.308 . In a recent study, Price and Gislason ${ }^{17}$ investigated the habit formation of Japanese consumption, utilizing time-series survey data from 1963-1991. Authors found that expenditure elasticity of cereal was -0.01 in short run and -0.015 in long run. This result indicates that the cereal, which includes all kinds of rice and noodles, is indeed an inferior product.

Our study however, has found that price and income elasticity for rice is -1.242 and -0.293 , respectively for the period of $1973-1991$ and -1.387 and -0.726 respectively for the period of 1991-2008. For both periods, rice is income elastic and classified as inferior good. The estimated income elasticities indicate that all food items are not luxury goods in Japan. But then why is the income elasticity for rice greater than some of other foods? The question arises because of our expectation of rice being a staple food. However, the robustness of our econometric results rather than the intuition should be used for reaching the conclusion on rice demand pattern in Japan.

iii) Is Rice Complement or Substitute for Meat, Fish, and Other Food Items?

Many time-series studies show that people consume more meat and poultry as per capita income increases. Japan is not an exception: the consumption of meats and poultry has been increasing, while the consumption of rice has been decreasing since the 1960s. However, due to the downward turn of economic condition especially after the bubble economy, Asian economic crisis in 1997 that continuously create economic uncertain until recently, has make the consumption for meat continuously decreasing except for pork; mainly because pork has a cheaper price.

Regarding to the history of calorie intake in Japan, Morishima, Aita, and Nakagawa ${ }^{18}$ have a succinct historical view from the early 1920s. Authors compare the budget share of 12 food items in 1970, 1980, and 1989. The budget share of grains decreases (from $16.9 \%$ in 1970 to $12.1 \%$ in 1989), while the budget share of food away from home (FAFH) increases substantially (from $9.3 \%$ in 1970 to $15.6 \%$ in 1989). This observation indicates that the consumption patterns are shifting from starchy food to non-starchy food and from consumption at home to FAFH. Tokoyama and Egaitsu ${ }^{19}$ investigate the trends in Japanese food consumption patterns in the period of 1963-1991. They classify per capita consumption patterns into varieties of ways to see the trends of goods. They conclude that saturation and stability characterize Japanese dietary patterns; the trends of foods demanded have been stabilized for a while. Recently, the preference for the higher quality food is replaced by the diversification and health concern in food consumption. In addition, due to the rise in the opportunity cost of labor for household work, the demand for convenient food rises.

17 D. W Price, and C. Gislason, 'Identification of habit in Japanese food consumption', Agricultural Economics, Vol.24, 2001, pp. 289-295.

18 M. Morishima, Y. Aita, and M.Nakagawa, 'Food consumption in Japan'. In L. Tweeten, C. Dishon, W.S. Chern, N. Imamura and M. Morishima, eds. Japanese and American agriculture: tradition and progress in conflict, Boulder, Colorado, USA, Westview Press, 1993, pp. 141-156.

19 H. Tokoyama, and F. Egaitsu, 'Major categories of changes in food consumption patterns in Japan 1963-91', Oxford Agrarian Studies, Vol. No.22, 2, 1994, pp. 191-202. 
As these studies show, the variety and nature of Japanese dietary patterns have shifted substantially over years, and it is important to understand the relationship of rice amongst other major food items. We estimate demand relationships among rice, noodles, fish and shellfish, dairy products, oil and fats, cakes and candies, juices, alcohol, fresh fruits, as well as fresh vegetables in order to investigate the substitution and complementary patterns and especially to know the position of fresh fruits among other fruits.

\section{v) Concluding Remarks for Rice Cross-sectional Analysis}

In this study, we estimate the Japanese demand for major 14 products: rice, noodles, fish and shellfish, dairy products, oil and fats, cakes and candies, juices, alcohol, fresh fruits, as well as fresh vegetables. Own-price, cross-price, and expenditure elasticities of major 14 products are estimated and analyzed. In conclusion, contrary to previous studies on rice consumption patterns, our empirical results show that own-price and expenditure elasticities for rice much higher. These results imply that Japanese rice is no longer a staple food, and indeed rice becomes inferior to many other foods. General dietary patterns of younger households can be characterized to be westernized; those households tend to consume more bread, noodle, other cereal, meat, and coffee and tea, which are not traditional Japanese food items. Utilizing 1974-2009 household survey data, econometric results indicate that the traditional Japanese dietary patterns have changed. Rice is not a staple food any longer, and other non-traditional Japanese food plays an important role in food consumption. Our study shows the evidence that rice is an inferior good.

\section{b) Meat demand analysis}

Meat and poultry consumption is getting more important in the Japanese diet. Some studies report that Japanese diets have become more and more westernized; as the per capita income increases; Japanese are consuming more meats and poultry than grain products. Furthermore, in June of 1988, Japan signed the Beef Market Access Agreement (BMAA) with the United States. This agreement might have accelerated the increasing trend of Japanese beef consumption due to an influx of cheaper beef from abroad. In general, Japan's meat production began to stagnate and later actually fall, while meat imports rapidly increased after the agreement.

In general the pattern of expenses for meat tallies with the quantity demanded as shown in Figure 2. Demand for meat has been increasing during the bubble economy and has been decreasing especially after 1994 to $44 \mathrm{~kg}$ per household. However, the demand for the meat bounced back after 2004 to increase from 39 to $41 \mathrm{~kg}$ per household..

Figure 3 below shows the consumption for beef, pork and poultry for by Japanese household from 1973-2008. The consumption for beef has been increasing from 1973 to 1995 but has been decreasing ever since. In case of pork, the consumption has been decreasing after 1980 but continuously increasing since 1997. The consumption for poultry on the other hand, has been decreasing especially after 1986; however, the consumption has been increasing since 5 years back. 
Figure 2 Japanese household consumption for meat 1973-2008

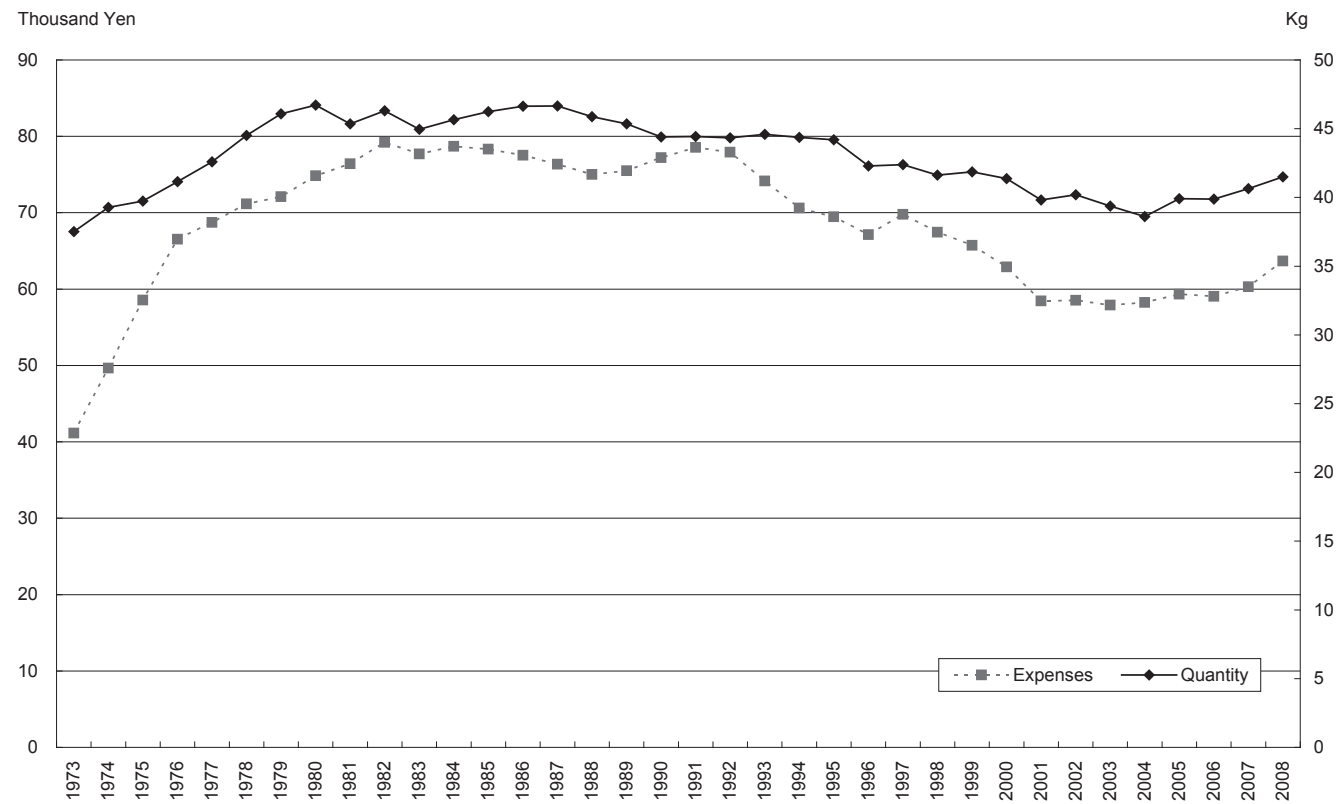

Source: http://worldfood.apionet.or.jp

Figure 3 Japanese household consumption for beef, pork and poultry 1973-2008

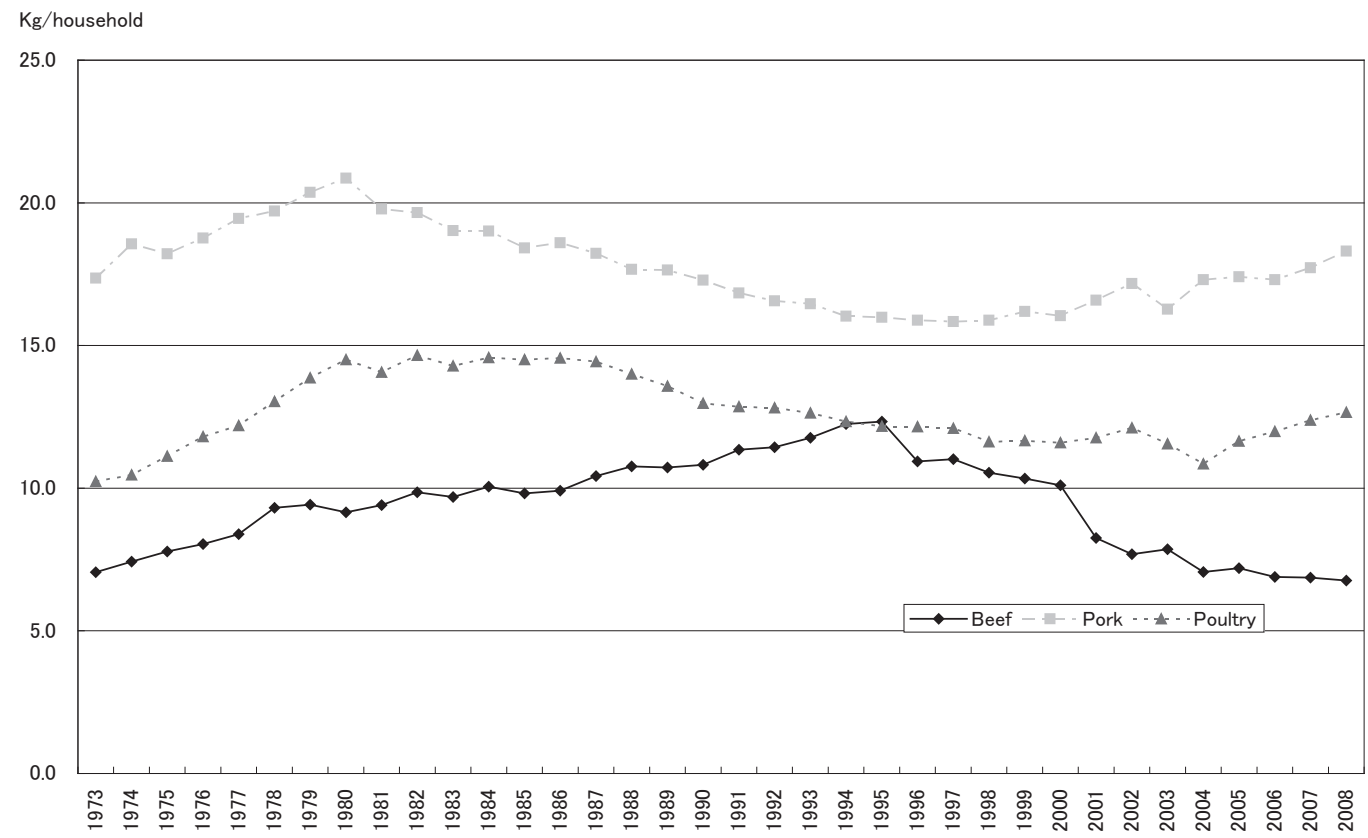

Source: http://worldfood.apionet.or.jp 
For meat as a whole, income elasticities have been fairly close to -0.743 during recent years. Consumption per household rose from $38 \mathrm{~kg}$ in 1973 to $41 \mathrm{~kg}$ in 2008. While it is very risky to try to postulate a maximum demand, all the evidence points to a substantial further rise before consumption begins to level out. The speed of this rise will probably be determined more by relative prices and physical availability than by average incomes. In other words, with unrestricted availability and prices attractive to consumers, consumption could rise considerably even in the short term. The principal meats consumed in Japan are pork, chicken and beef in that order. Mutton and lamb, whale meat and horsemeat together amount to a little more than beef in quantity. While beef is the preferred meat, the allocation of consumption between the various meats is determined mainly by price and availability. Pork is main meat consumed by Japanese household. The responses to the supplies were increased rapidly in response to demand, and household consumption rose from $15.6 \mathrm{~kg}$ in 1996 to $18.3 \mathrm{~kg}$ in 2008 . Chicken consumption increased from $10.8 \mathrm{~kg}$ per per household in 2004 to $12.4 \mathrm{~kg}$ in 2008. On the other hand, beef has been decreasing since 1994 from $12.3 \mathrm{~kg}$ per household to only $6.8 \mathrm{~kg}$ per household in 2008 . The decreases is due to the increase in price as well as reduce in import especially from the United States due to the beef diseases.

\section{c) Fresh fruits demand analysis}

The consumption of fruit per capita has increased almost four-fold in the past 40 years, income elasticities being variously estimated at between 1.097 and 0.799 .

Per household consumption for fresh fruits has been declining since it peaks on 1973 as shown in Figure 3. According to Figure 3, the decreases of the demand for fresh fruits decline before 1992 is mainly due to the increase in price. However, the demand

Figure 4 Japanese household consumption for fresh fruits 1973-2008

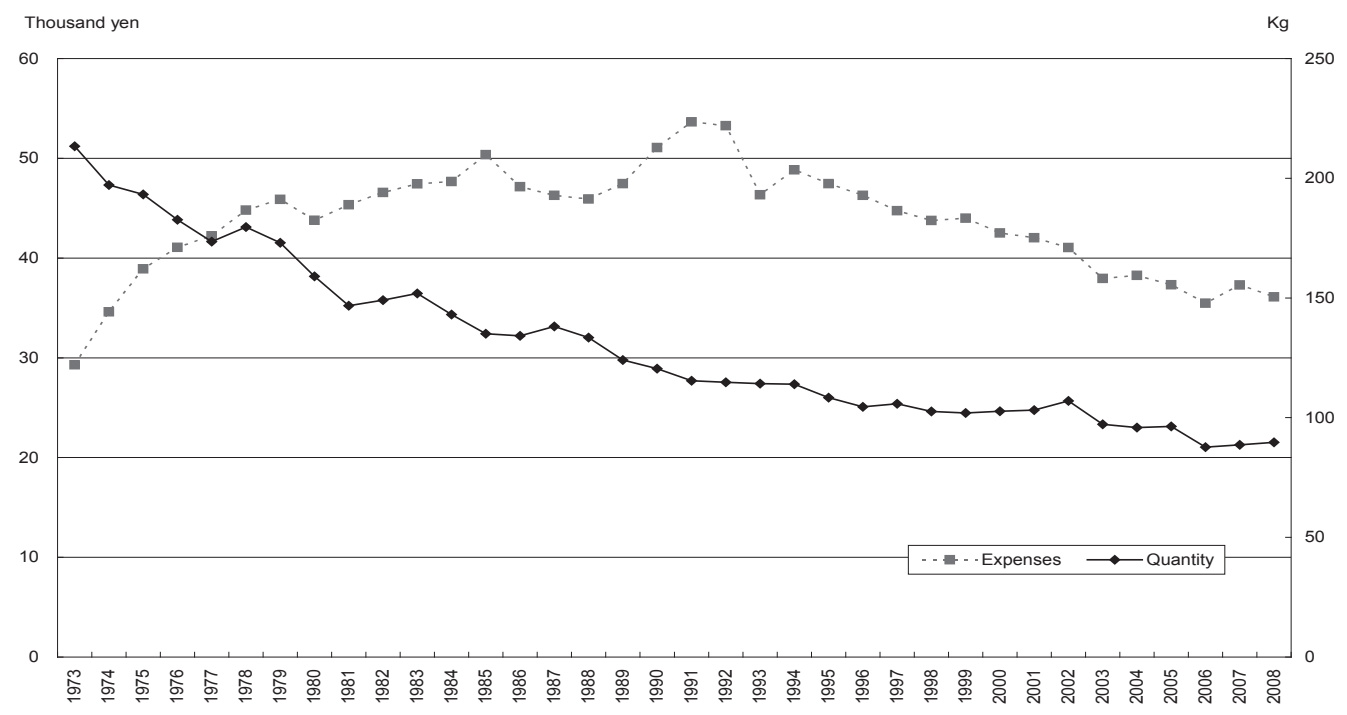

Source: FIES, 1974-2009 
Figure 5 Japanese price and per capita consumption for fresh fruits 1973-2008

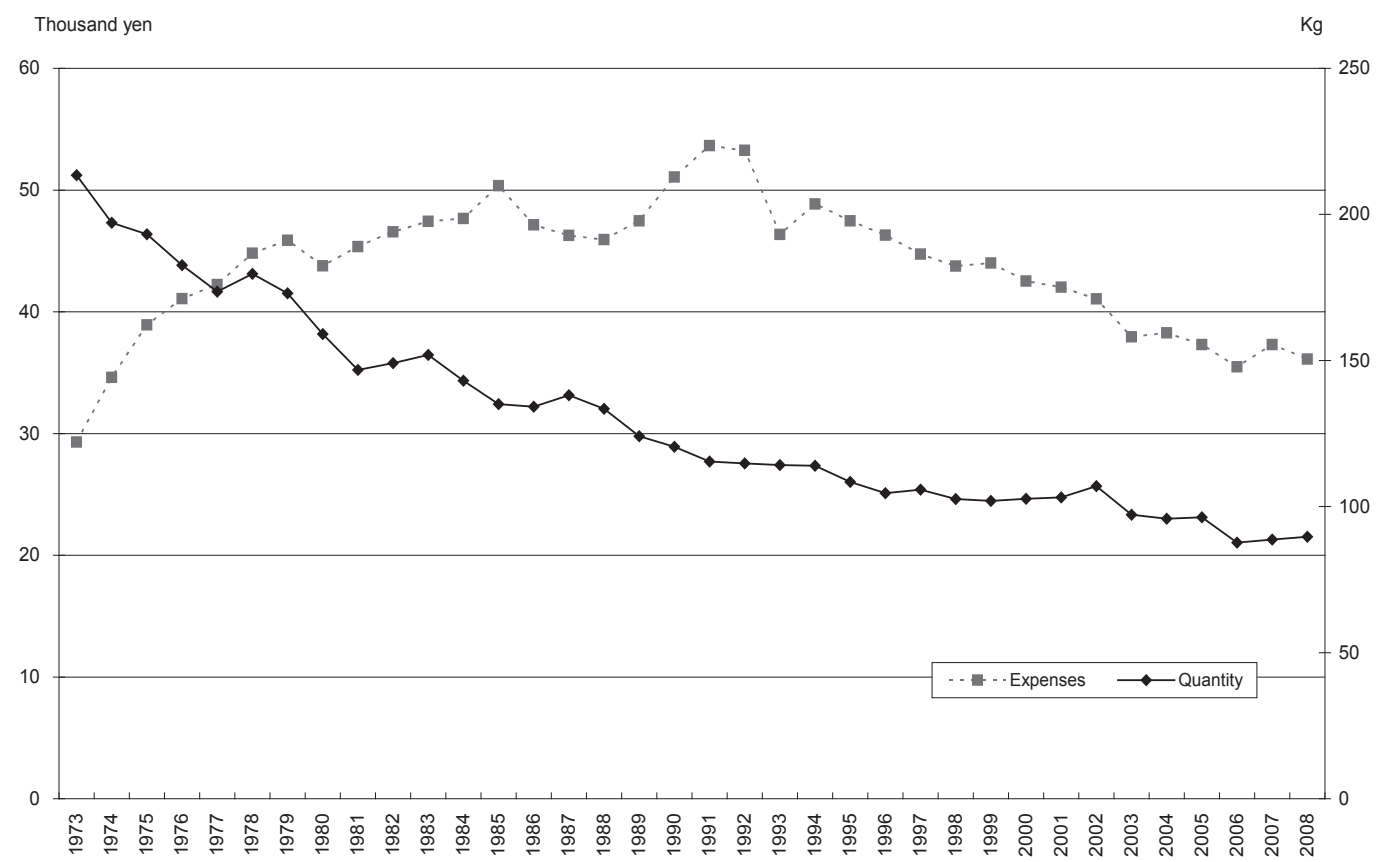

Source: FIES, 1974-2009

for the fruits did not goes upward with the decreasing in price after the period due to several factors such as time consuming, availability of other food, changing life styles, etc.

The most widely used fruit in Japan is mikan (mandarin orange), per capita consumption of which rose from $3.1 \mathrm{~kg}$ a head in 1955 to $23.1 \mathrm{~kg}$ in 1973 . However, per capita household for mikan has been declining ever since to $7.81 \mathrm{~kg}$ in 1990, $6.01 \mathrm{~kg}$ in 2000 and $4.15 \mathrm{~kg}$ in 2008 . The income elasticity for mikan as calculated from time series data has for 1973-1991 is 0.799 and 0.184 for 1991-2008 with the cross-section elasticity is much lower, showing that this fruit is not really a favorite among consumers. The decline in price of mikan relative to other fruits in recent years as shown in Figure 3 has no effect on the declining trend of this fruit. However, a considerable increase is expected in mikan used for juice.

Demand for apple fluctuates parallel with the price as shown in Figure 4. Imports of apples are permitted from very few countries, ostensibly for quarantine reasons. In this situation, elasticity calculated for apples have very little meaning and in any case have recently not been significantly different from zero. Unless imports are permitted, further declines in consumption appear inevitable, the area devoted to apples having declined. Bums recorded very high income elasticity when they first came on the market following import liberalization, but these fell rapidly as supplies increased and bananas ceased to be a novelty. Japanese government has introduced new rules on banning the import for mikan and apple during the winter season in order to decrease the competition with the local production. 
14 Abdullah Alias, Hajime Kobayashi, Ichizen Matsumura, Hassan Maizom, Zakaria Mustafa, Md Nasrudin Md Akhir, Rohayati Paidi, Asmadi Hassan and Mohd Ikbal Mohd Huda

Figure 6 Japanese price and per capita consumption for mikan and apple 1973-2008

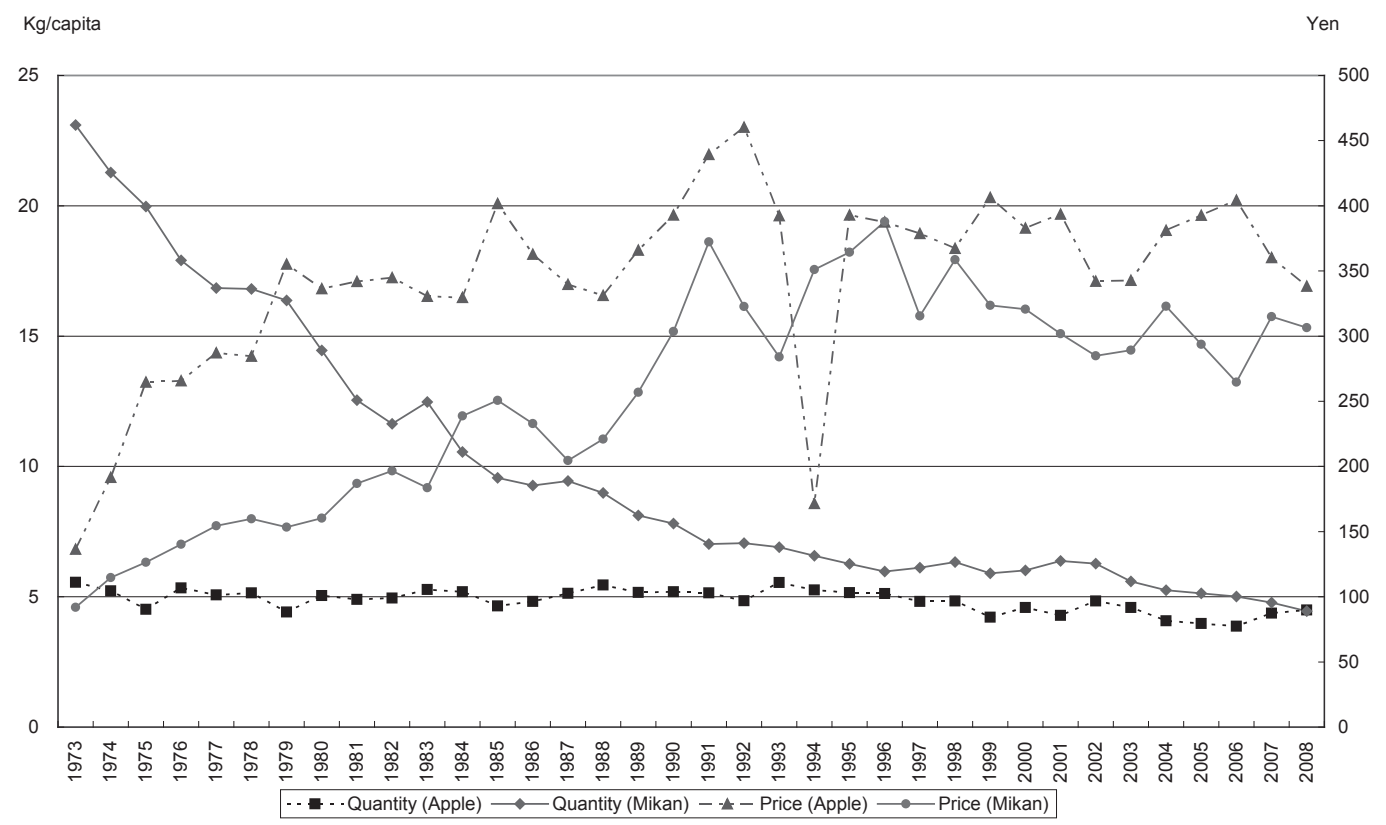

Source: FIES, 1974-2009

The demand for other 12 types of fresh fruits by Japanese consumer is shown in Table 4. Recently, per capita consumption for grapefruits, orange, other citrus, and persimmon shows positive trend; vice versa with the demand for pear, grape, peach, watermelon, melon, banana and strawberry. Further demand analysis for fresh fruits will be discussed in detail in the next chapter in order to investigate the reason(s) and also the demand situation for all 14 most important fresh fruits in Japan.

Table 4 Japanese per capita consumption for 12 types of fresh fruits, 1973-2008

\begin{tabular}{|c|cccccccccccc|}
\hline Year & Grapefruits & Orange & $\begin{array}{c}\text { Other } \\
\text { Citrus }\end{array}$ & Pear & Grape & Persimmon & Peach & Watermelon & Melon & Strawberry & Banana & Other Fruits \\
\hline 1975 & 0.15 & 0.13 & 0.89 & 2.66 & 1.33 & 0.94 & 0.99 & 5.71 & 3.75 & 1.11 & 4.91 & 1.70 \\
1980 & 0.21 & 0.19 & 1.31 & 2.41 & 1.29 & 1.02 & 0.82 & 3.47 & 4.07 & 1.32 & 3.67 & 1.82 \\
1985 & 0.34 & 0.31 & 2.02 & 2.33 & 1.35 & 1.11 & 0.71 & 2.95 & 4.71 & 1.20 & 3.38 & 2.22 \\
1990 & 0.27 & 0.37 & 1.34 & 2.00 & 1.11 & 1.15 & 0.62 & 2.51 & 5.62 & 1.27 & 3.68 & 2.43 \\
1995 & 0.64 & 0.51 & 1.38 & 1.93 & 1.01 & 0.98 & 0.61 & 1.99 & 5.02 & 1.12 & 4.19 & 2.34 \\
2000 & 0.62 & 0.34 & 1.22 & 2.06 & 1.02 & 1.13 & 0.70 & 2.05 & 4.05 & 1.25 & 5.83 & 1.77 \\
2001 & 0.60 & 0.31 & 1.26 & 1.98 & 0.92 & 1.11 & 0.76 & 2.07 & 4.58 & 1.21 & 5.40 & 1.83 \\
2002 & 0.65 & 0.28 & 1.34 & 1.98 & 1.00 & 1.05 & 0.78 & 1.91 & 4.16 & 1.22 & 5.18 & 2.16 \\
2003 & 0.69 & 0.32 & 1.15 & 1.65 & 0.91 & 0.65 & 0.58 & 1.48 & 4.30 & 1.17 & 5.39 & 2.00 \\
2004 & 0.84 & 0.31 & 1.33 & 1.57 & 0.83 & 0.91 & 0.64 & 1.58 & 4.35 & 1.14 & 5.73 & 2.14 \\
2005 & 0.58 & 0.33 & 1.26 & 1.83 & 0.92 & 1.01 & 0.70 & 1.67 & 3.89 & 1.13 & 5.91 & 1.82 \\
2006 & 0.59 & 0.33 & 1.36 & 1.86 & 0.90 & 1.22 & 0.76 & 1.76 & 3.77 & 1.11 & 6.20 & 1.81 \\
2007 & 0.81 & 0.50 & 1.72 & 1.62 & 0.81 & 0.98 & 0.73 & 1.30 & 0.85 & 1.07 & 6.41 & 1.90 \\
2008 & 0.86 & 0.51 & 1.79 & 1.61 & 0.80 & 1.12 & 0.63 & 1.46 & 0.84 & 1.00 & 7.40 & 2.05 \\
\hline
\end{tabular}

Source: FIES, 1974-2008 


\section{(d) Vegetable demand analysis}

Generally, the demand for vegetables in Japan is being decreased. According to USDA, Japan`s food self-sufficiency ration on vegetable is gradually decreased to $80 \%$ started from 2004. Japan imports many kinds of vegetable from various countries, with more than $60 \%$ from China.

Figure 7 Japanese per household consumption for vegetable 1973-2008

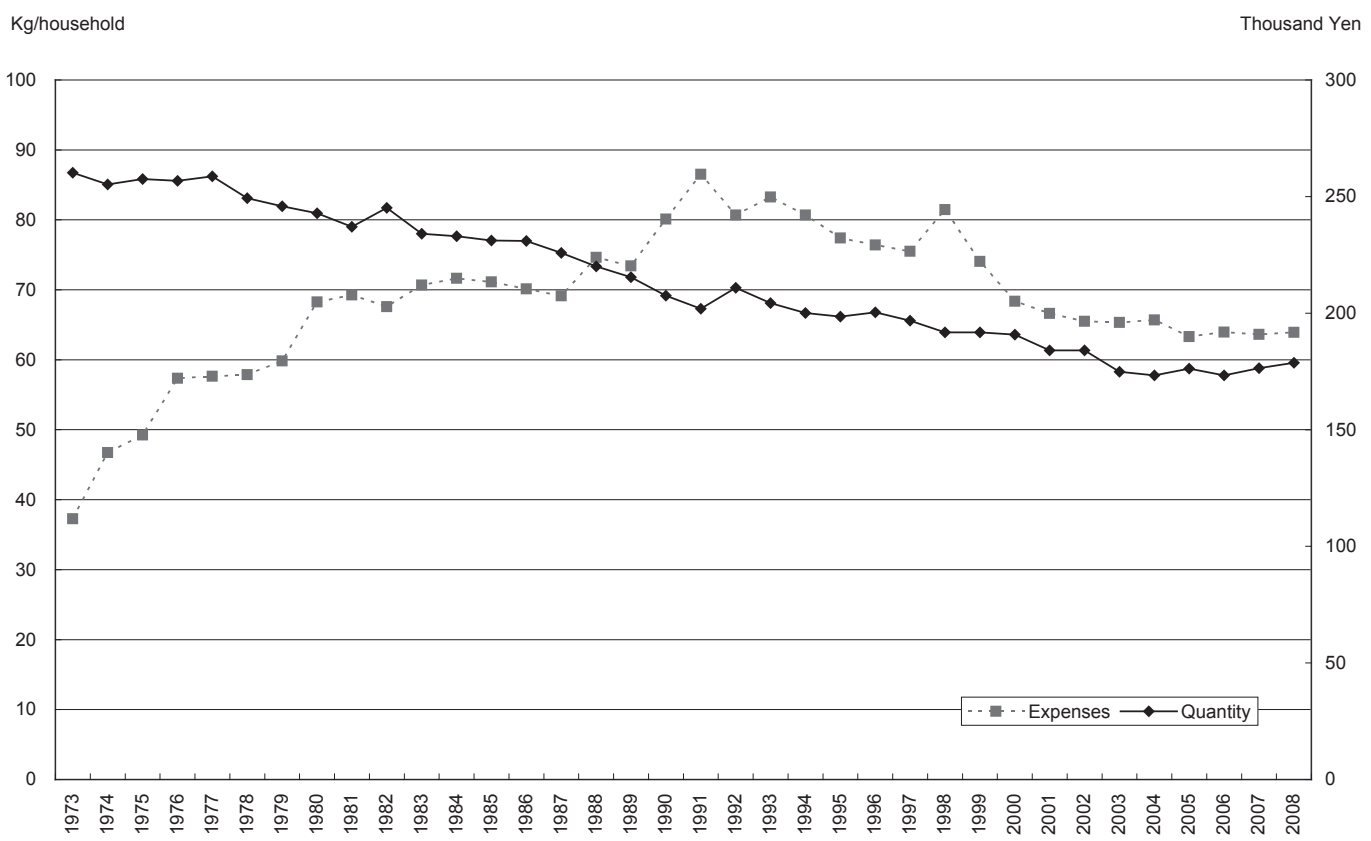

Source: FIES, 1974-2009

Per capita consumption for Japanese household has been declining from $260 \mathrm{~kg}$ per household in 1973 to $179 \mathrm{~kg}$ per household in 2008 as shown in Figure 5. The decreases in price 1991 did not help to boost the intake for fresh vegetables. Price elasticity for vegetables has change from the price inelastic of -0.870 for the period of 1973-1991 to the price elastic of -1.264 for the latter period of 1991-2008. Japanese consumer's taste in vegetables is generally very conservative and consumers are still very pricing conscious. In recent years, a demand has been developing for organic vegetables. Within the vegetable group, there has been a trend away from root crops towards leafy and western type vegetables, but since few vegetables are imported, the composition of consumption will continue to be determined mainly by availability and relative prices, which will in turn influence the composition of production.

\section{(e) Other Cereals, bread and noodles demand analysis}

Figure 6 shows the Japanese household demand for other cereals, bread and noodles. The rapid decline in the use of barley and other coarse grains for human consumption 
is reflected in large negative income elasticities for these products. Wheat, bread, cereal products, and noodles have recently exhibited low income elasticities, but bread consumption in particular has been quite responsive to price. Cereals other than rice, wheat and barley for beer are used mainly as livestock feed and the demand for them is derived from the demand for livestock products which are dealt with separately. Bread becomes more popular especially for breakfast. Many young Japanese generation preferred bread because of the healthiness, taste and less time consuming in preparing those food. Noodles is very famous among Japanese consumers especially soba, udon and ramen. As for some Japanese, the popularity of noodles makes the consumption of rice decline as they change their regularity of eating rice with those noodles. The preparation for noodles much easier and less time consuming compared to the rice especially instant noodles. The demand for all cereals, bread and noodles combined seems to be tending upward towards the average for all food consumption, especially in the recent years.

Figure 8 Japanese per household consumption for other cereals, bread and noodles 19732008

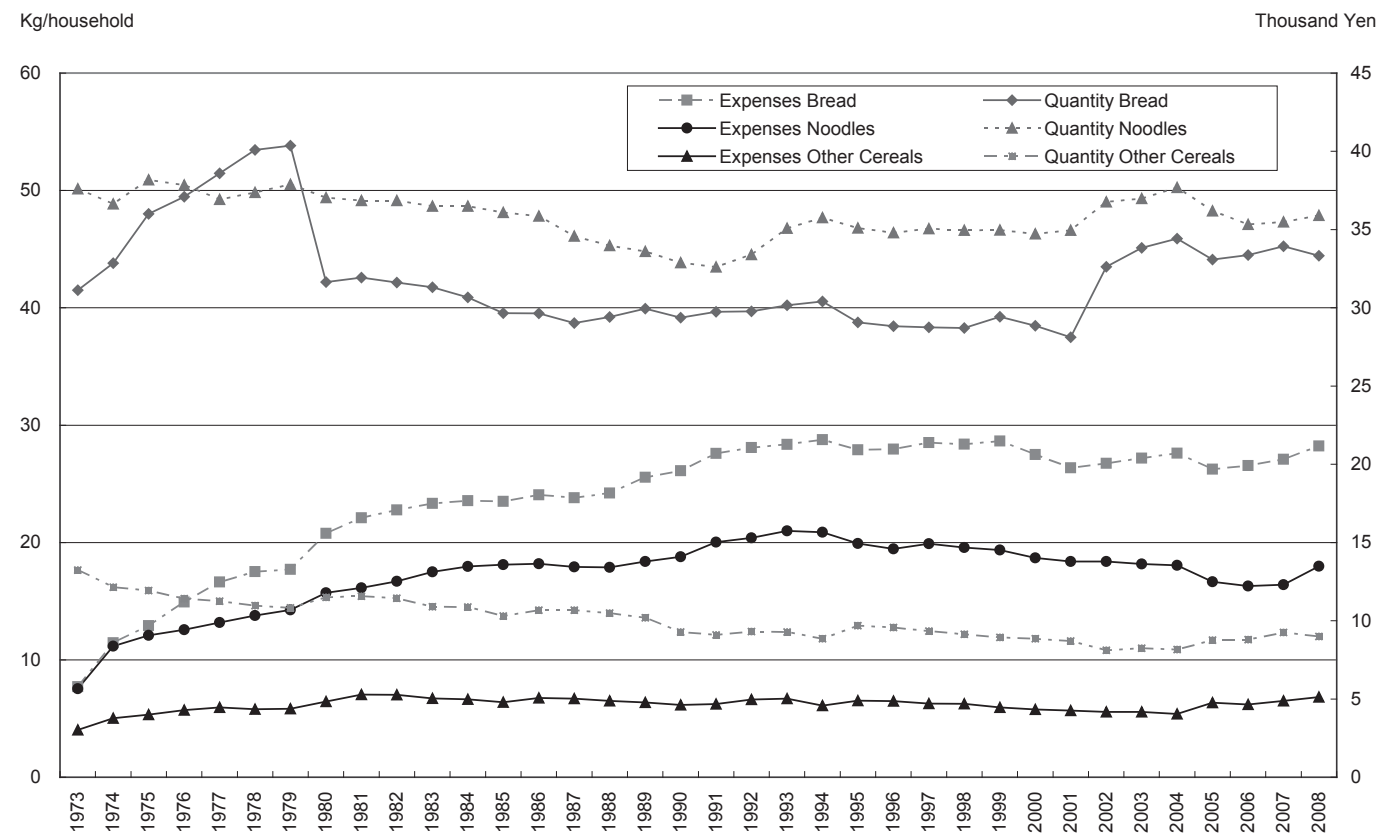

Source: FIES, 1974-2009

\section{(e) Dairy products, cakes and candies, and oil and fat demand analysis}

Over the period 1973-1991 and 1991-2008, the price elasticity for dairy products has increased from 0.792 to 1.313 . As shown in Figure 7, consumption per household falls from $203 \mathrm{~kg}$ in 1973 to $120 \mathrm{~kg}$ in 2008 and has recently leveled out to some extent. The quantity of milk consumed other than as fresh milk has usually been rather less than 
half the total and has increased to a rather smaller extent. Consumption of cheese has continued to increase in recent years, but increases in purchases of butter and powdered milk appear to have ceased. The reason for this is by no means clear since prices for dairy products have risen less than fresh milk prices and considerably less than prices for food as a whole. Elasticities calculated for these dairy products have usually been of low statistical significance and it is difficult to assess the potential for future increases. Income elasticity for dairy products has been decreasing from 1.388 (luxury product) to 0.549 (normal product) for 1973-1991 and 1991-2008, respectively.

The demand for cakes and candies has been leveled up since 1995 after the risen phase from 1973-1996 as shown in Figure 7. Price elasticity for cakes and candies has been increase from 0.247 (price inelastic) to 2.164 (price elastic) for 2 period. Income elasticity for both periods has shown that the elasticity has not go so much change from 1.339 to 1.240. Japanese consumers still considered cakes and candies as luxury good.

The quantity of demand per household for oil and fats has not shown any significance changes. Per household demand for oil and fats in 1973 is $12 \mathrm{~kg}$; been decrease by $2 \mathrm{~kg}$ after 39 years. Price and income elasticity for oil and fats is 0.925 and 0.806 for 1973-1991, and 1.093 and 0.228 for 1991-2008. Oil and fats is normal good for Japanese consumer since 40 years ago.

Figure 9 Japanese per household consumption for dairy product, cakes and candies, and oil and fats, 1973-2008

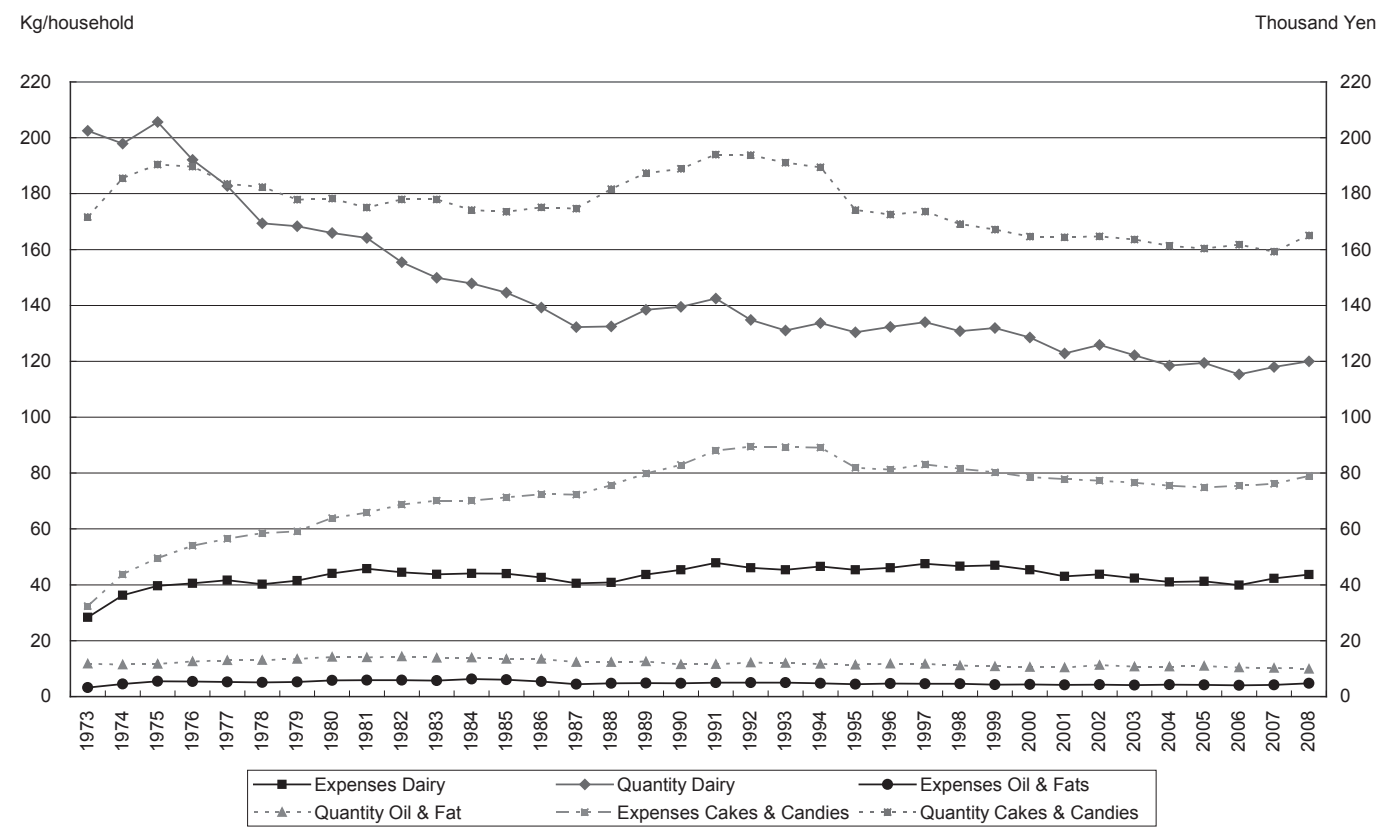

Source: FIES, 1974-2009

\section{(f) Fish and shellfish demand analysis}

Japan has long been one of the highest fish and shellfish consumer in the world and further substantial increases do not appear likely, except perhaps if meat supplies fall 
well short of demand. Whether supplies can be increased to this extent on a long-term basis is open to doubt, since there have been supply difficulties in some years. At the same time, consumers have sought to maintain their fish consumption and supply shortages which have occurred from time to time have been reflected in price increases for fish which considerably exceed the average for other foods. Despite the decreases in price, per household consumption for fish and shellfish has continuously decrease from $60 \mathrm{~kg}$ in 1975 to $30 \mathrm{~kg}$ in 2008. Price elasticity for fish has been increasing almost double from 0.805 in 1973-1991 to 1.485 for 1991-2008. Income elasticity however, has been declining by half from 1.180 to 0.687 for both periods.

Figure 10 Japanese per household consumption for fish and shellfish, 1973-2008

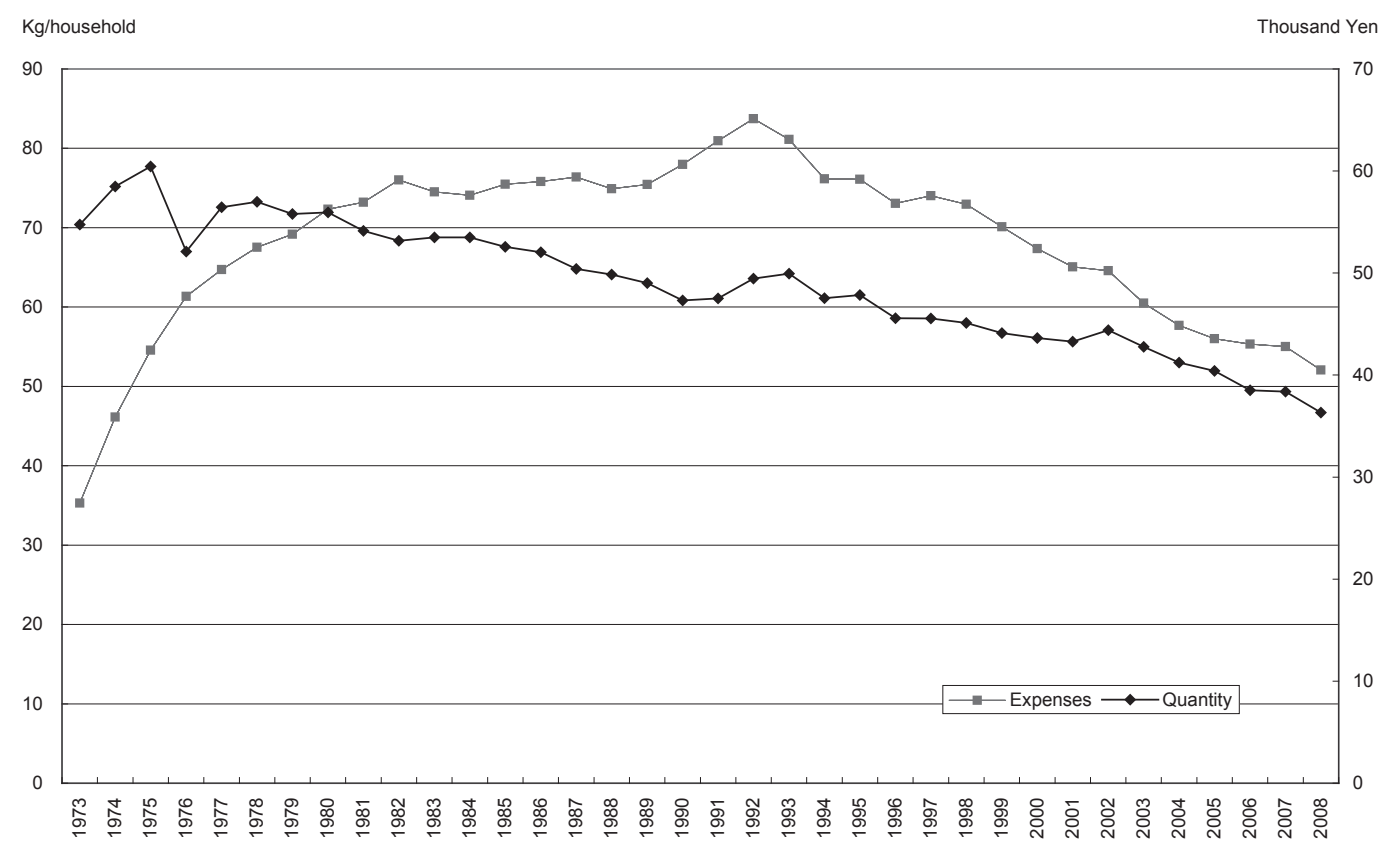

Source: FIES, 1974-2009

\section{(g) Alcohol, coffee and tea, and juices demand analysis}

Traditionally, the Japanese society was relatively tolerant of alcohol consumption by middle-aged men, while disapproving of such behavior among young people and women. Sixty percent of problem drinkers are salaried businessmen who claim that getting drunk with clients or coworkers is part of their job and a mark of company loyalty. To refuse a drink from the boss is a terrible insult that can damage a career. Although alcohol consumption is now decreasing in most industrialized countries, it has quadrupled in Japan since 1960. However, household consumption for alcohol has been fluctuating in decreasing phase since 1973 due to the increases in price. On the other hand, the decreasing trend of alcohol consumption after 1994 despite the decreases in price. In fact, the price has been decreasing since 1994 in order to attract consumer to 
consume more alcoholic beverages. The Japanese households consume $183 \mathrm{ml}$ alcohol in 1973, decrease to $176 \mathrm{ml}$ in 1994 and $139 \mathrm{ml}$ in 2008 as shown in Figure 9.

Figure 11 Japanese per household consumption for alcohol, 1973-2008

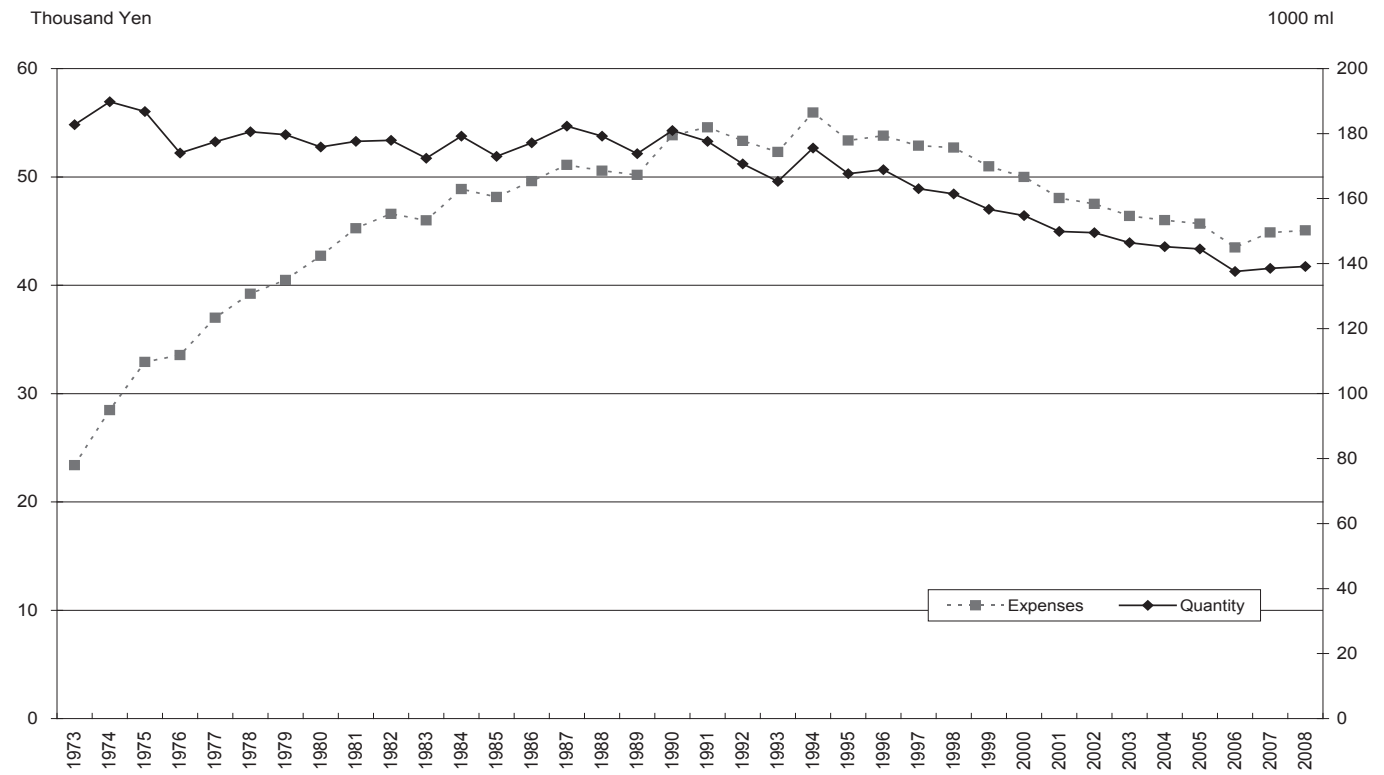

Source: FIES, 1974-2009

The prices of imported fruit and vegetable juices are dependent on harvests and domestic production, and as such, there is some yearly fluctuation on both the volume and value of imports. Overall, fruit and vegetable juice imports (in total) peaked in 1995 after years of steady growth and declining. However, in recent year's fruits juices import increasing due to increase in consumption. The liberalization of apple juice, grape juice, and pineapple juice imports in 1990 and orange juice imports in 1992 allowed the importation of juices priced lower than their domestic counterparts, leading to increased imports, but these fruit juices in turn have faced competition from non-sugar soft drinks. Orange juice and apple juice vie for the number one position among fruit juices. After the 1992 liberalization, orange juice imports grew rapidly, exceeding apple juice by as much as $60 \%$ by 1994 . Orange juice imports slowed considerably since, however, and apple juice imports, which remained strong in the meantime, again approximate orange juice imports. One of the reasons cited for the recent decline in fruit and vegetable juices imports is the slowdown in household consumption as shown in Figure 10 is caused by the recession, but an even greater reason is competition from mineral water and non-sugar soft drinks. Japanese still drink relatively little fruit and vegetable juices at breakfast, causing the slowdown in imports. A significant development of recent years is the growth in the imports of organically grown fruit and vegetable juices. Many beverage manufacturers are willing to develop new products made from organically grown fruit and vegetable juices, and this, according to one estimate, will cause imports of organically grown fruit and vegetable juices to increase by as much as $10 \%$ a year. 
Abdullah Alias, Hajime Kobayashi, Ichizen Matsumura, Hassan Maizom, Zakaria Mustafa, Md Nasrudin Md Akhir, Rohayati Paidi, Asmadi Hassan and Mohd Ikbal Mohd Huda

The major constraint to the acceptance of organically grown fruit and vegetable juices are their high price-if the price difference decreases, the share of such juices, which accounts for about $10 \%$ of all juices at present, will likely increase.

Figure 12 Japanese per household consumption for fruit and vegetable juices, 1973-2008

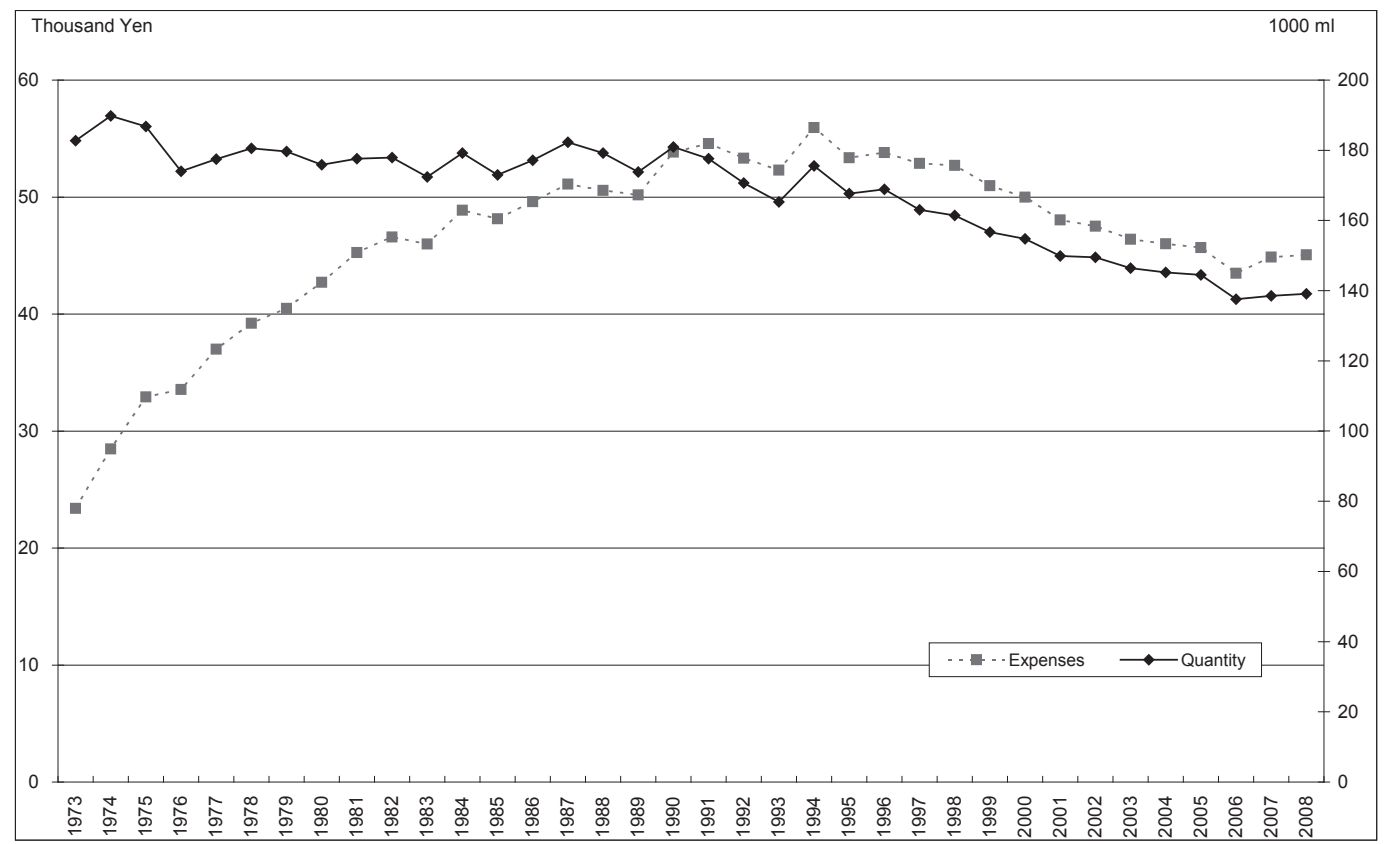

Source: FIES, 1974-2009

A generation ago, very few Japanese touched coffee. By the 1980s there were over 100,000 coffee houses. By 2000, coffee had become a $\$ 8.12$ billion industry with every man, woman and child consuming an average of 331 cups a year. Coffee drinking has tripled since 1970 and continues to go up. Bottled and canned coffee accounts for 30 percent of the drink market. The Japanese invented canned coffee drinks. Some Japanese are fond of coffee made with newly-harvested beans. The Japanese take tea drinking quite seriously and regard themselves as experts on the matter. One of the first pieces written by Japanese in English (in the late 19th century) was The Book of Tea, which explained why Japanese tea was superior to the teas found in other places. Tea, including green tea, mugicha, oolong tea and black tea, account for 26.7 percent of $\$ 30$ billion canned and bottled nonalcoholic drink market. Kyoto and Shizuoka prefectures are Japan's main tea-growing areas. In some parts of Fukuoka Prefecture people mix the tea leaves from a finished pot of tea with soy sauce and eat it. In Japan, tea consumption (money basis) in the home is about 16 percent of all drinks. During last two decades, the consumption of tea has been continuously decreasing. This tendency suits as results of change in Japanese meal and life style. By far green tea had been served only with hot water inside tea cups. Recently, however, new goods of green tea in cans and PET bottles 
were developed and the demand for these is largely increased. As shown in Figure 11, the consumption for coffee and tea by Japanese household has been decreasing for the period of 1973-1996 and bounced back from 1986 to 2005 with little decrease from 20052008. The decrease in the recent years happens maybe because of a bit increase in price.

Figure 13 Japanese per household consumption for coffee and tea, 1973-2008

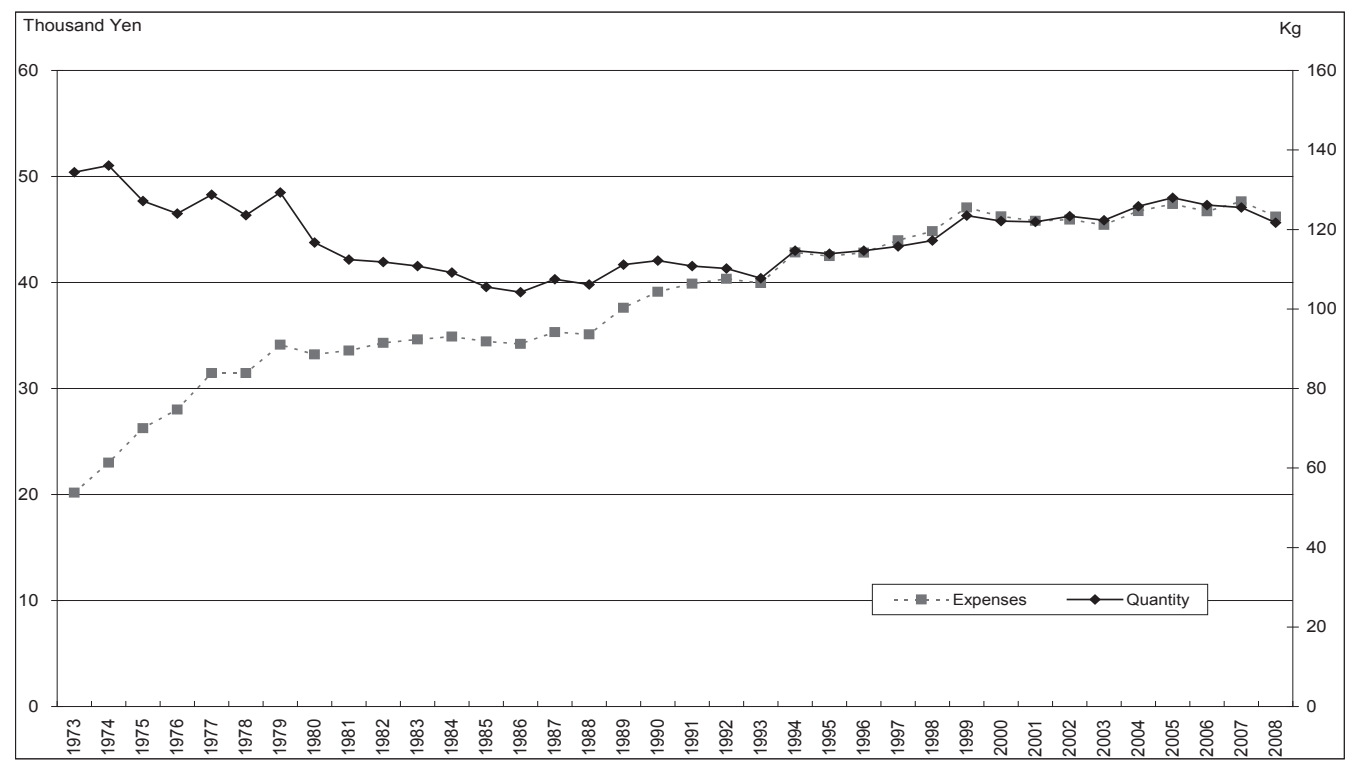

Source: FIES, 1974-2009

\section{Conclusion}

This report documents the research results from modeling food consumption behavior by Japanese households using the household-level data from 1973-2008. The Family Income and Expenditure Survey (FIES) data offers rich information and data for estimating food demand in Japan. In this study, we only present one empirical food demand models - one for 14 aggregate foods including rice, bread, noodles, other cereals, dairy products, fish and shellfish, meat, fruits, vegetables, cakes and candies, oil and fats, alcohol, coffee and tea and juices (fruit and vegetable). There are, of course, more can be done with this database. We will continue our collaborative efforts to learn more about Japanese food consumption behavior from this unique data source.

This report presents analyses of descriptive statistics of food consumption by Japanese household and econometric estimation of the double logarithmic econometric model for the period of 1973-1991 and 1991-2008. Our econometric results indicate that Japanese rice is an inferior good, and demographic variables are important indicators of the future trend of Japanese rice consumption. According to our meat demand analysis, Japanese dietary patterns have become more and more westernized. One puzzling set of results is related to the estimated own-price elasticity of rice demand. Our estimates 
of this elasticity for 1973-1991 range from -0.247 to -1.242 , which are low and between -0.743 to -2.164 , which are very high.

Since this elasticity has important implications for the impacts of Japanese agricultural and trade policies, it needs to be carefully assessed. We note, however, the survey data are observations of purchase behavior, which may not be the same as the consumption behavior. This is especially true for rice because households buy rice in response to changes in price. We note there were substantial variations on rice prices among households and months. We suspected that the differences might have been caused by quality differences. High-income households tend to buy higher quality of rice than lower income households. We attempted to address this question by estimating various demand models by income level. However, the estimates of the own-price elasticity of rice remain very similarly high. We are unable to address the question on the differences between purchase and actual consumption in this study. The issue is important and we should try to employ a more elaborated modeling framework based on the concept of infrequency of purchase.

Some of our findings contradict with previous studies from aggregated time-series data. We hope that these findings shed more lights on the continuing debate about the income and price effects of food demand, especially for rice in Japan. The results presented in this report should also be useful to agricultural policy makers in assessing the impacts of various agricultural and trade policies.

\section{References}

Abdullah, A., Hajime K. and Ichizen M., Japanese Household Demand for

Fresh Fruits, 1991-2006: Based on Cities with Prefectural Government and Highly Populated Cities, Journal of Farm Management. Vol. 47 (2), 2009, pp. 216-221.

Alias Abdullah, Hajime Kobayashi, Ichizen Matsumura, Shoichi Ito, 'World Rice Demand Towards 2050: Impact of Decreasing Demand of per Capita Rice Consumption for China and India'. In Japan and East Regionalism, Md. Nasrudin Md Akhir and Asmadi Hassan (eds), Department of East Asian Studies, University of Malaya, 2008.

Annual Report on the Family Income and Expenditure Survey 1965-2010, Ministry of Internal Affairs and Communications, Japan, 1965-2010.

Annual Report on the Consumer Price Index 1960-2006, Ministry of Internal Affairs and Communications, Japan.

Bouis, H.E., Rice in Asia: Is it becoming a commercial good? Commentary, American Journal of Agricultural Economics, Vol.73, 1991, pp. 522-527.

Chern, W.S., 'Assessment of demand side factors affecting global food security'. In W.S. Chern, C.A. Carter and S.-Y. Shei, eds. Food security in Asia: economics and policies, Northampton, Massachusetts, USA, Edward Elgar, 2000.

Deaton. A and Muellbauer J., 'Economics and Consumer Behavior', Cambridge: Cambridge University Press. Economics Vol. 75, 1980, pp.259-68.

FAO/WHO, Workshop on Fruit and Vegetables for Health: Fruit and vegetables for health: Report of a Joint FAO/WHO Workshop, September, 2004, Kobe, Japan, Retrieved July 5, 2007, http://www.who.int/dietphysicalactivity/publications/ fruit_vegetables.report.pdf. 
FAO Food and Agriculture Organization, 'Medium-Term Prospects for Agricultural Commodities : Projections to the Year 2010', 2003, Retrieved July 1, 2010, http:// fao.org/docrep/006/y5143e/y5143e00.htm.

FAO Food and Agriculture Organization, 'Analysis of Food Consumption Behaviour by Japanese Household', 2002, Retrieved July 1, 2010, http:/ /www.fao.org/ docrep/007/ae025e/ae025e00.htm.

Fujiki, H., Japanese Rice Market Liberalization: A Competitive Equilibrium Approach, Kyoto: Kyoto Institute of Economic Research at Kyoto University, 1998.

Gehrt, K. C., Shim S., The Role of Fruits in the Japanese Gift Market: Situationally Defined Markets, Agribusiness. John Wiley \& Sons, Inc., 1998.

Huang, J., and Howard B., Structural Changes in the Demand for Food in Asia, Washington, D.C.: International Food Policy Research Institute, 1986.

Huang, K. S., Demand for Food: A Complete System of Price and Income Effects. TB-1714. U.S. Department of Agriculture, Economic Research Service, 1985.

Ito, S., Wesley P., and Warren G., Rice in Asia: Is It Becoming an Inferior Good? American Journal of Agricultural Economics Vol.71, 1989, pp. 32-42.

Japan Tariff Association (JTRADE). Japan Tariff Association, Retrieved August 16, 2007, http://www.kanzei.or.jp/english/.

Kako, T., Gemma, M. \& Ito, S., Implication of the minimum access rice import on supply and demand balance of rice in Japan, Agricultural Economics, 16, 1997.

MAFF, Statistics and Information Department. Food Balance Sheet, Ministry of Agriculture, Forestry and Fisheries 2001, Management and Coordination Agency, "1995 Input-Output Tables," Government of Japan, 1999.

Morishima, M., Aita, Y. \& Nakagawa, M., 'Food consumption in Japan'. In L. Tweeten, C. Dishon, W.S. Chern, N. Imamura and M. Morishima, eds. Japanese and American agriculture: tradition and progress in conflict, Boulder, Colorado, USA, Westview Press, 1993, pp. 141-156.

Mori, H., John D., Susan P., and Kimiko I., 'Age-Free Income Elasticities of Demand for Foods: New Evidence From Japan', Annual Buletin of Social Science, No. 40, Senshu University, 2006, pp. 17-47.

Parker, M. P., The 2007-2012 Outlook for Fresh Fruits in Japan, Icon Group International Inc., 2006.

Price, D.W. \& Gislason, C, 'Identification of habit in Japanese food consumption', Agricultural Economics, Vol.24, 2001, pp. 289-295.

Sasaki, K., 'Consumption behavior of Japanese agricultural households: analysis of an almost ideal demand system', Journal of Rural Economics, Vol. 67, No.3, 1995, pp. 141-150.

Sawada, H., 'Estimation of food demand system: Rotterdam demand system approach', Hokusei Ronsyu, Vol.18, 1980, pp. 147-161.

Sawada, M., 'Changes in total expenditure distribution and aggregate food demand of household sector', Journal of Rural Economics, Vol.54, No.4, 1983, pp. 185-195.

Sawada, M., 'A hierarchical model of demand for food in Japan', Journal of Rural Economics, Vol.56, No.3, 1984, pp.163-173.

Sawada, M., 'The effects of prices, income and household characteristics on food demand: a demand system approach', Journal of Rural Economics, 57(4), 1986, pp. 229-239.

Tokoyama, H. \& Egaitsu, F., 'Major categories of changes in food consumption patterns in Japan 1963-91', Oxford Agrarian Studies, Vol.22, No.2, 1994, pp. 191-202. 

Jurnal EAJIR Bab 1.indd 24 